\title{
The Dichotomous Responses Driven by $\beta$-Defensins
}

\author{
Jennifer R. Shelley, Donald J. Davidson and Julia R. Dorin* \\ Centre for Inflammation Research, The University of Edinburgh, Edinburgh BioQuarter, Edinburgh, Scotland
}

Defensins are short, rapidly evolving, cationic antimicrobial host defence peptides with a repertoire of functions, still incompletely realised, that extends beyond direct microbial killing. They are released or secreted at epithelial surfaces, and in some cases, from immune cells in response to infection and inflammation. Defensins have been described as endogenous alarmins, alerting the body to danger and responding to inflammatory signals by promoting both local innate and adaptive systemic immune responses. However, there is now increasing evidence that they exert variable control on the response to danger; creating a dichotomous response that can suppress inflammation in some circumstances but exacerbate the response to danger and damage in others and, at higher levels, lead to a cytotoxic effect. Focussing in this review on human $\beta$-defensins, we discuss the evidence for their functions as proinflammatory, immune activators amplifying the response to infection or damage signals and/or as mediators of

OPEN ACCESS

Edited by:

Charles Lee Bevins, University of California, Davis,

United States

Reviewed by:

Gill Diamond

University of Louisville, United States Joost Joe Oppenheim, National Cancer Institute at Frederick, United States

${ }^{*}$ Correspondence: Julia R. Dorin Julia.Dorin@ed.ac.uk

Specialty section

This article was submitted to Microbial Immunology,

a section of the journal

Frontiers in Immunology

Received: 16 March 2020

Accepted: 13 May 2020

Published: 12 June 2020

Citation:

Shelley JR, Davidson DJ and Dorin JR (2020) The Dichotomous Responses Driven by $\beta$-Defensins.

Front. Immunol. 11:1176. doi: 10.3389/fimmu.2020.01176 resolution of damage, contributing to a return to homeostasis. Finally, we consider their involvement in the development of autoimmune diseases.

Keywords: beta defensin, psoriasis, atopic dermatitis, autoimmunity, immunomodulation, AMP

\section{INTRODUCTION}

Defensins and defensin-like peptides are found throughout multicellular organisms including plants, insects and fungi, as well as vertebrates. They were first described as antimicrobial peptides (AMP), with the ability to rapidly penetrate and disrupt the outer membrane of bacteria, viruses and fungi to varying degrees and subsequently disrupt metabolic processes within (1). It is appealing to consider that this innate, protective mechanism is so fundamental that the defensin genes have been evolutionarily conserved for this purpose. In fact, the value of the structure of these disulphide-stabilised, cysteine containing, positively charged loop peptides has resulted in two evolutionarily distinct defensin families that have arisen separately by convergent evolution (2). The cis-defensin superfamily (present in insects, fungi and plants), has the central beta-strand stabilised by disulphide bridges, connected to the same alpha-helix in the "cis" orientation. This is in contrast to the vertebrate (and some invertebrate) defensins, in which the central beta strand has disulphide bridges that stabilise structures in non-cis or "trans" orientations $(3,4)$. Both cis and trans families have undergone rapid expansion and evolutionary change to reveal a repertoire of diverse functions that are only recently becoming clear (5).

Here we focus on the human, trans-defensins-specifically $\beta$-defensins. We discuss their role(s) in host defence other than by direct microbial killing. We consider whether the function of these molecules is purely as an acute "alarmin"-type response to danger/damage (alerting the body and promoting both local innate, and also local and systemic adaptive immune responses), or if they are also instrumental in controlling inflammation (limiting the damage response and mediating resolution) - thus speeding a return to homeostasis. 


\section{BETA-DEFENSIN BACKGROUND}

The defensin family is a large, multigene family that is rapidly changing and evolving. In humans there are two functional subfamilies of defensins ( $\alpha$ and $\beta$ ) which differ in their cysteine connections but retain the central structure of a trans-defensin cysteine knot. Both $\alpha$ - and $\beta$ - defensins are generally encoded by two (sometimes three) exons, with the first exon containing the hydrophobic, anionic leader sequence and the second exon encoding the mature, cationic peptide. The $\alpha$-defensins are stored in this inactive form in the granules of either neutrophils or intestinal Paneth cells, while $\beta$-defensins are expressed predominantly in epithelial cells and believed to be cleaved by signal peptidase as they are secreted (6).

$\beta$-defensins are an ancient family, from which the $\alpha$-defensins have evolved. The amino acid sequence of human $\beta$-defensins is highly divergent, and has been subject to complex positive and negative selection (7). During this process, other than the cysteines, only a core glycine and aspartic acid are wellconserved. $\beta$-Defensins have an identifiable consensus sequence of $\mathrm{X}_{2-10} \mathrm{CX}_{5-7}(\mathrm{G} / \mathrm{A}) \mathrm{XCX}_{3-4} \mathrm{CX}_{9-13} \mathrm{CX}_{4-7} \mathrm{CCX}_{\mathrm{n}}$ and the three disulphide connections following oxidation are assumed to be the same for all $\beta$-defensins $\left(\mathrm{C}_{\mathrm{I}}-\mathrm{C}_{\mathrm{V}}, \mathrm{C}_{\mathrm{II}}-\mathrm{C}_{\mathrm{IV}}\right.$, and $\left.\mathrm{C}_{\mathrm{III}}-\mathrm{C}_{\mathrm{VI}}\right)$. The highly variable residues in the mature peptide are rich in the positively charged amino acids lysine and arginine to varying degrees (7). Some of the peptides have extended peptide tails with clusters of lysines and residues for additional potential glycosylation sites (8). In the human genome there are five $\beta$ defensin clusters located over three chromosomes, with around 33 genes, of which only a few have known function $(9,10)$ and seven of which (in humans) are hyper copy number variable (CNV) (5). The many gene duplications in the defensin family result in gene "birth and death" and as the gene number and sequence changes, some genes become specialised for a new function; while at the species level, there are increased numbers or complete loss of gene clades. Mice, for example, have different numbers of cryptdins (intestinal $\alpha$-defensins) even between different strains of Mus domesticus (11) and no longer have neutrophil expressed $\alpha$-defensin genes. The sequence diversity and gene number variation in the defensin genes is not surprising as strain specific diverse regions (SSDR) between mouse strains are highly enriched for genes involved in immunity, infection and reproduction functions, all of which are associated with defensins (12).

Gene duplication and sequence change, followed by selection for advantageous changes, allows functional change of paralogues. The structure of some off-shoots of the main $\beta$-defensin tree has been so advantageous that there are examples of both reptiles (snakes and lizards) and mammals (egg laying platypus) independently giving rise to venom toxins, with a variety of actions that include antimicrobial function (13) and potassium channel blocking ability (14). Additionally, Kudryashova et al. (15) showed that both $\alpha$ and $\beta$-human defensins could target, destabilise and inactivate bacterial protein toxins (16). This work implies that defensins may have protective abilities that are not limited to microbe destruction. Intriguingly, and perhaps indicative of roles of immunological modulation/damage, the human defensin HBD2 has been shown to bind to the outer pore domain of potassium channel Kv1.3 and efficiently inhibit channel currents and suppress IL-2 production in both human primary $\mathrm{T}$ cells and peripheral mononuclear cells (17).

At this point, the expression pattern of $\beta$-defensins in humans is worthy of mention [see useful reviews on this here $(18,19)]$. All the many $\beta$-defensin members are strongly expressed in various segments of the epididymis post puberty $(20,21)$ and a major function of $\beta$-defensins is in sperm maturation. A $\beta$-defensin mutation in human DEFB126 was found to reduce sperm motility and fertility in Chinese men (22). In addition, mice deleted for several $\beta$-defensins (in pairs or more) are infertile and this demonstrates their synergistic function in sperm maturation, movement and protection against premature acrosome reaction $(23,24)$. Sperm are rich in $\beta$-defensin in the glycocalyx of the head and this may protect the sperm from inappropriate activation. However, mice with transgenic over-expression of an epidydimal specific $\beta$-defensin (orthologous to human $\beta$ defensin SPAG11), while being resistant to $E$. coli infection, simultaneously show reduced expression of inflammatory cytokines IL- $1 \alpha$ and IL-1 $\beta$, indicating multiple functions and implying immunomodulatory properties.

Expression of $\beta$-defensins is not just evident in the male genitourinary system, as these peptides are also widely expressed in other tissues. In this review we are focussing primarily on HBD1-4, as these genes are the most studied in human. Their peptide sequence, gene name and charge are given in Table 1. HBD1-3 are found in the female reproductive tract in endometrium, vagina and cervix, while HBD1 is found in fallopian tubes (26). These defensins are increased in expression at a number of sites in the body, including the tracheal epithelium, gingival mucosa, respiratory epithelium, gastrointestinal epithelium, genitourinary tract epithelium and skin (27-30). In addition, HBD1 is produced constitutively in a range of other epithelial tissues, including the small intestine, pancreas, and kidney. Expression of HBD1 may also be increased in various cell types following viral stimulation (31) and both HBD2 and HBD3 are inducible proteins, with expression occurring in various cell types in response to infection $(32,33)$, proinflammatory cytokines (including IL-1 $\beta$, IL-17,TNF $\alpha$, and IL-22) (34-36) and injury. The response to these inducers is not the same for every gene or for every condition. For example, plasma levels of $\beta$-defensins are variable in individuals with asthmatic vs. normal airways, where HBD3 is elevated by HBD1 and 2 are reduced (37). HBD3 and HBD4 are significantly increased, but HBD2 is decreased. The level of mouse DEFB14 was also increased in asthmatic animals. Expression may also be varied by genomic copy number of DEFB103, DEFB4, DEFB104 but DEFB1 does not show copy number variation (CNV). Both copy number and promoter sequence variation has been shown to contribute to expression of DEFB4 and DEFB103 $(38,39)$, but inflammatory stimuli can override these.

This widespread pattern of expression, and inducibility in infection and inflammation, raises the question of what is the principle function of these peptides? A number of studies have been conducted addressing whether $\beta$-defensins act as 
TABLE 1 | Mature Peptide sequence of the four human $\beta$-defensins described most commonly in the literature.

\begin{tabular}{llll}
\hline PEPTIDE & GENE & Mature peptide sequence & Charge \\
\hline HBD1 & DEFB1 & DHYNCVSSGGQCLYSACPIFTKIQGTCYRGKAKCCK & 4 \\
HBD2 & DEFB4 & GIGDPVTCLKSGAICHPVFCPRRYKQIGTCGLPGTKCCKKP \\
HBD3 & DEFB103 & GIINTLQKYYCRVRGGRCAVLSCLPKEEQIGKCSTRGRKCCRRKK \\
HBD4 & DEFB104 & ELDRICGYGTARCRKKCRSQEYRIGRCPNTYACCLRKWDESLLNRTKP & 6 \\
\hline
\end{tabular}

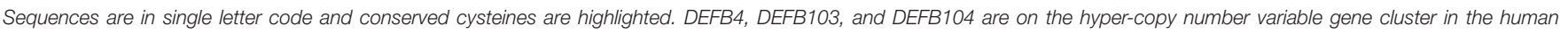

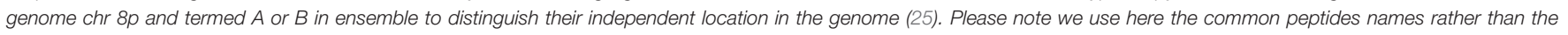
official designated peptide names (e.g., HBD1 instead of DEFB1etc.). Net charge at pH 7 calculated using https://pepcalc.com/.

immune or inflammatory modulators, but it is important to bear in mind that synthetic preparation and oxidation of defensins is not trivial. Correct cysteine disulphide bonding and oligomerisation may have an important effect on function as has been shown for the chemoattractive role of defensins (40). In some cases, recombinant peptides have been used, which poses some concern regarding contamination with Lipopolysaccharide (LPS). Some $\beta$-defensins are highly charged molecules and their structure in vivo can be monomeric or dimeric, oxidised or reduced, depending on the tissue, with known effects on both antimicrobial and other function(s) (40-43). In addition, apart from the reproductive tract, where expression is strong and constitutive, $\beta$-defensins are generally expressed at very low levels until induced by inflammatory mediators. The concentration of peptide used in in vitro experiments is therefore likely crucial to determine the true in vivo effect. Thus, studies using peptides in vitro are important, but may not always reflect physiological functional relevance. With those consideration in mind, we discuss below the evidence for $\beta$-defensins as host defence peptides, able to modulate the immune system in various ways (see Figure 1).

\section{BETA-DEFENSINS AS ALARMINS}

Alarmin is a term first coined by Yang and Oppenheim, for endogenous molecules that act as signals for tissue and cell damage (45). They are characterised by a number of central principles, which include the ability to recruit and activate innate immune cells, and bridge to and/or promote adaptive immune responses, whether through direct or indirect mechanisms $(46,47)$. Increasingly, $\beta$-defensins are shown to be involved in pathways of this type, acting as both chemokines for adaptive immune cells and as innate immune stimuli (detailed below). This is suggestive of an alarmin role for these peptides.

\section{Chemokines}

Both $\beta$ and $\alpha$-defensins can act as chemoattractants for immune cells (see Figure 1). Some years ago the similarity of defensin structure to chemokines was noted, alongside recognition that many chemokines can have antimicrobial activity under similar experimental conditions to those under which defensins were studied $(48,49)$. In addition, similarly to chemokines, defensins bind glycosaminoglycans (GAG) and oligomerise (50). Various human $\beta$-defensins can attract immune cells including immature dendritic cells, memory $\mathrm{CD}^{+} \mathrm{T}$ cells, monocytes, and activated neutrophils at low $(\sim 10-100 \mathrm{ng} / \mathrm{ml})$ concentrations, similar to known chemokines $(\sim 0.02 \mu \mathrm{M})(40$, $51,52)$. When this chemoattractant ability was first described, it was a very exciting observation, revealing defensins as a bridge between the innate response and adaptive immune cell recruitment. CCR6 (receptor for CCL20) was identified as a receptor through which defensins could mediate chemotaxis of lymphocytes and neutrophils, with structural similarities to CCL20 being detected (51-53). However, it was also shown that an as yet unidentified receptor, independent of CCR6, could mediate chemoattraction of CD4 $+\mathrm{T}$ cells and dendritic cells by a murine $\beta$-defensin (54). In addition, monocytes were shown to be attracted by HBD3 and this activity was shown to be dependent on the cysteine stabilised structure, whereas antibacterial activity was not (40). Interestingly, restoration of a single cysteine (cysV) was sufficient to enable human monocyte chemoattractant activity for HBD3 and its mouse orthologue Defb14 (55). Of physiological relevance, in vivo studies only found evidence for the HBD2-mediated attraction of macrophages (and not dendritic cells) following intraperitoneal injection of mice with the peptide $(54,56)$. Subsequently, CCR2 was shown to be a macrophage receptor through which HBD3 (and Defb14) could induce monocyte/macrophage cell movement (57). Indeed, HBD3 expression has been suggested to result in tumour associated macrophage attraction in vivo through CCR2 (58). In addition, HBD1, 2, and 4 can all have their expression increased by $\Delta \mathrm{Np} 63$ in normal and squamous cell carcinomas and exert a chemotactic activity for (lymphatic) endothelial cells in a CCR6-dependent manner (59).

In addition to these direct chemoattractant properties, defensins can also function indirectly by inducing chemokine expression. Human keratinocytes exposed to a high concentration $(30 \mu \mathrm{g} / \mathrm{ml} ; \sim 6 \mu \mathrm{M})$ of HBD-2, -3 , or -4 , increase the gene expression and protein production of IL-6, IL-10, IP-10, CCL2, CCL20, and RANTES. The treated cells displayed enhanced $\mathrm{Ca}^{2+}$ mobilization, chemoattraction, proliferation and phosphorylation of epidermal growth factor receptor (EGFR); signal transducer and activator of transcription (STAT)1, and STAT3 (60). This pro-inflammatory response was markedly suppressed by $\mathrm{G}$ protein coupled receptor inhibitors. 


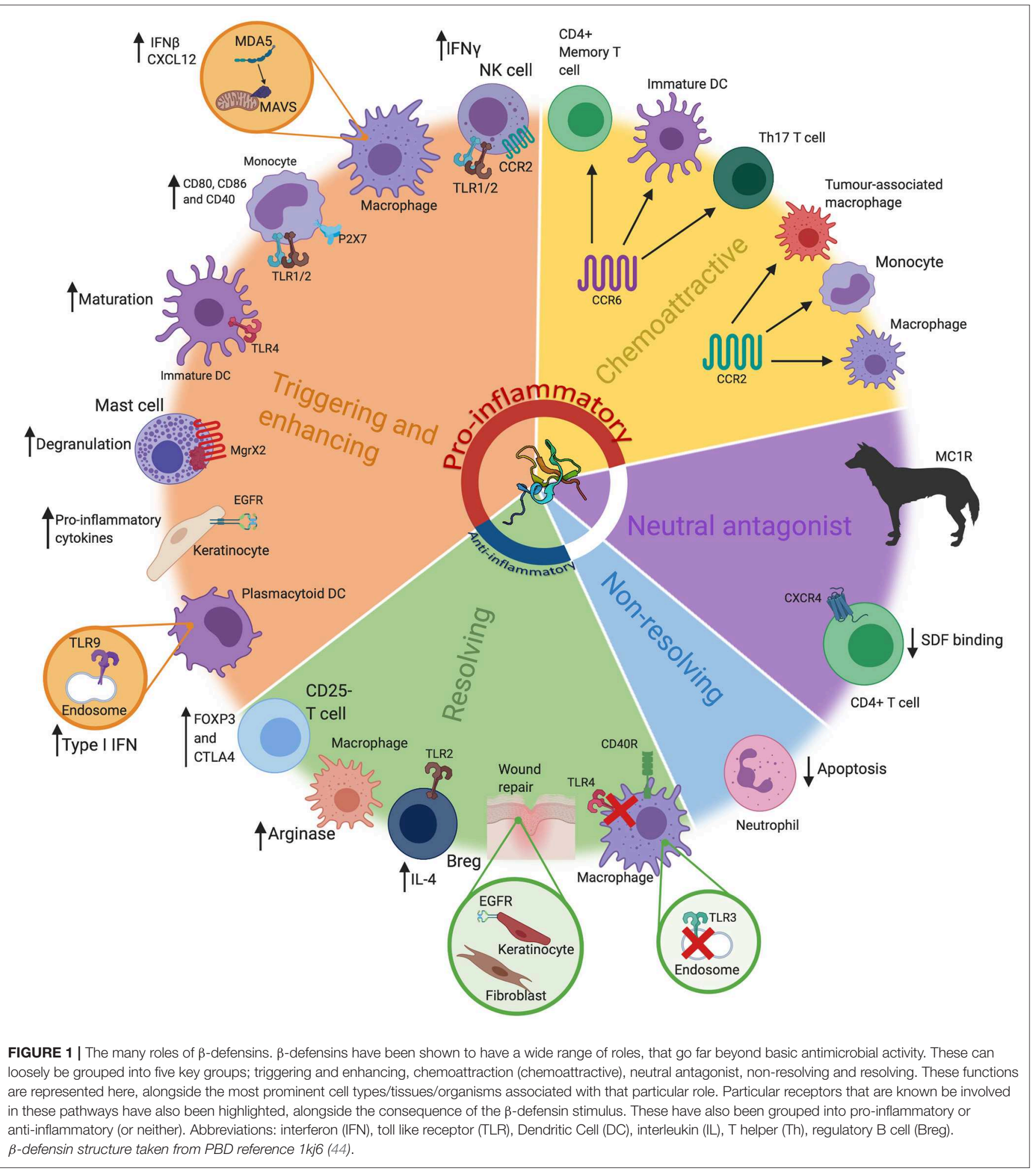

\section{Innate Triggers}

In addition to acting to promote chemotaxis of a range of immune cells, the $\beta$-defensins have a range of other modulatory functions that expand their repertoire beyond simplistic microbicidal activity (see Figure 1). A proinflammatory response to $\mathrm{HBD} 3$ was observed in monocytes, when a robust concentration of $3.8 \mu \mathrm{M}(20 \mu \mathrm{g} / \mathrm{ml})$ was used to induce an increase in co-stimulatory molecules CD80, CD86m and CD40 and proinflammatory cytokines in a TLR1/2 dependent manner (61). However, unlike TLR2 ligands, HBD3 did not increase 
levels of IL-10 and did not reduce co-stimulatory molecule expression (62). At $1 \mu \mathrm{M}(5 \mu \mathrm{g} / \mathrm{ml}) \mathrm{HBD} 3$, we see no evidence of proinflammatory responses in primary macrophages. At $5 \mu \mathrm{M}$ and above, HBD3 can cause membrane damage in monocytes (but not $\mathrm{B}$ and $\mathrm{T}$ cells) through interaction with the negatively charged phospholipids (63), thus care is required to consider the concentrations at which cellular stress responses to supraphysiological conditions might occur. HBD3-mediated CD86 expression (but not CD80) was shown to be induced via the ATP-gated channel P2X7 (64). Similarly, recombinant mouse $\beta$-defensin 2 (Defb2 peptide) was shown to induce maturation of dendritic cells via TLR4, proposing it as a potential adjuvant, although this was only observed with a fusion protein incorporating this peptide, and not with peptide alone (65).

\section{Innate Enhancement}

In addition to these stimulatory effects of antigen presenting cells, defensins have been shown to alter cellular processing, and inflammatory responses to DNA and RNA. In plasmacytoid dendritic cells (pDC), enhanced intracellular uptake of CpG or self-DNA was observed when the DNA was associated with either HBD3 or HBD2 at a 1:2 $\mu \mathrm{M}$ ratio, thus promoting TLR9dependent IFN- $\alpha$ production in both human and mouse $(66,67)$. This was also observed with bacterial DNA in human and mouse pDC, but a response to self-DNA was only seen in the human cells (68). It is likely that these observed increases in ligand uptake and TLR9 signalling are due to the ability of these cell-penetrating peptides to increase the transport of the DNA into the cells (69). However, HBD3 is also able to oligomerise and may increase the ability of the DNA to interact with TLR9 effectively. This has been shown for HBD3 and another cationic host defence peptide cathelicidin, LL-37, as well as other cationic peptides. Schmidt et al. (70) elegantly showed that the peptides can form columnar nanocrystalline complexes with dsDNA and that the distance between the DNA columns influence a stronger or weaker interaction with the TLR9 receptor, which signals to produce type I interferon (71). Importantly these effects have also been observed in vivo, with intravenous injection of mice with $\mathrm{CpG}$ DNA:HBD3 complexes generating increased IL-6, IFN- $\gamma$, IL$12 \mathrm{p} 70$, IL-10, and IFN- $\alpha$ in the serum $24 \mathrm{~h}$ later when compared to CpG DNA alone, and an increase in antigen presenting cells in the spleen (66).

In addition, primary mouse macrophages, when prestimulated for $4 \mathrm{~h}$ with a fusion protein of IgG1 and the mouse orthologue of HBD3, Defb14, then subsequently stimulated for $24 \mathrm{~h}$ with endosomal (TLR3 and TLR9) or heterodimer (TLR1/2) ligands, showed an increase in proinflammatory cytokines and chemokine CXCL12, independent of the presence of CCR2 or CCR6 (72). The Defb14 fusion did not induce a cytokine signal on its own. These studies reveal a complex interplay with other factors, via which these defensins may contribute to enhanced adaptive responses.

Our lab has shown that the presence of HBD3 alters innate signalling to double stranded RNA poly I:C, increasing the Interferon- $\beta$ (IFN $\beta$ ) response and decreasing CXCL10 (IP10) production in vivo and in vitro in both mouse and human primary macrophages (73). PolyI:C is a synthetic double stranded
RNA (dsRNA) and consequently acts as a mimic of virus or product of damaged cells. It is recognised by endosomally located TLR3 and also by cytoplasmic RIG-I-like receptors (RLRs). High molecular weight (HMW) poly I:C preferentially signals through the RLR MDA5 (Melanoma DifferentiationAssociated protein 5), also known as IFIH1 (interferon induced with helicase $C$ domain 1 ) and produces Interferon $\beta$ (IFN $\beta$ ). We showed that $0.1 \mu \mathrm{M}$ HBD3 enhanced poly I:C-mediated MAVS (IPS-1) and MDA5 signalling, increasing IFN $\beta$, but decreased TLR3 stimulation and CXCL10 signalling (72) in primary murine macrophages. The peptide rapidly entered the macrophages (within $10 \mathrm{~min}$ ), decreased the endosomal localisation of the HMW PolyI:C and increased cytoplasmic localisation. This contrasted with the effect of the cationic lipid lipofectamine on HMW PolyI:C, which increased endosomal signalling through TLR3. LL-37, a cathelicidin cationic AMP with some similar immunomodulatory actions to HBD3 (74), can also increase dsRNA induced signalling through MAVS and TLR3 to increase production of proinflammatory cytokines and IFN $\beta$ in keratinocytes (75). For TLR3 this is partially due to the alpha helical LL-37 peptide forming crystalline structures with dsRNA which matches the steric size of TLR3, allowing recruitment and engagement of multiple TLR3 receptors and an increased cytokine signalling response (76) in a similar way to peptide-induced DNA association with TLR9. The increased signalling by MDA5 in the presence of HBD3 and HMW polyI:C might also be structurally dependent. Of note, linear HBD3 peptide does not increase IFN $\beta$ production and MDA5 normally forms filaments around dsRNA for oligomerization; we therefore speculate that this may be optimised in the presence of correctlyfolded HBD3 (77).

The properties of other immune cells can also be modified by exposure to defensins, to promote host defence mechanisms. In the presence of $\mathrm{HBD} 3$, human NK cells increase CD69 C-Type lectin protein expression and secrete IFN $\gamma$, killing the NK sensitive myeloid cell line K562. In addition, HBD3 can function through the Mas related gene X2 to activate and initiate degranulation of mast cells $(78,79)$. Other cationic amphipathic peptides, such as LL-37, have also been shown to have this capacity.

Finally, defensins may modulate cell death, with possible consequences for inflammation. $\beta$-defensins have been shown to downregulate the pro-apoptotic truncated protein Bid and upregulate the anti-apoptotic Bcl-xL, leading to inhibition of mitochondrial membrane potential change and decreased caspase 3 activity and apoptosis (80). HBD3 is the most potent of the human $\beta$-defensins in this regard. Neutrophil apoptosis is important in resolution of tissue damage, thus limiting apoptosis may also be pro-inflammatory. In contrast, in human airway smooth muscle cells, the addition of HBD3 (at high concentrations of 5 or $10 \mu \mathrm{M}$ ) has been shown to induce CCR6dependent production of IL-8 and cell apoptosis. This apoptotic effect appeared to be induced by ERK1/2 MAPK and ROSinduction (37). This may be important context for scenarios in which higher concentrations of the peptide are seen to be inflammatory and leading to cytotoxic effects. Cytotoxicity has been seen for high concentrations of HBD3 (over $20 \mu \mathrm{M}$ ) in 
a wide variety of cells in culture, including DC, normal and immortalised keratinocytes and primary oral gingival epithelial cells (81).

\section{Receptor Neutral Antagonism}

There are several examples of defensins acting as promiscuous ligands for receptors (see Figure 1) helping to explain the pleiotropic properties observed. This may be due to complementary electrostatic interaction between the cationic peptide and receptors with anionic regions. HBD3, the most highly charged $\beta$-defensin (charge of +11 ) has been demonstrated to be a neutral antagonist, through charge based interaction with melanocortin receptor 1 and 4 (82). In dogs, a three base pair deletion in the canine orthologue of HBD3 results in an increase in the level of expression, which then allows this peptide to promiscuously bind the melanocortin receptor 1 (MC1R) - resulting in dogs with black, rather than agouti, fur (83). When the mutant or wildtype dog genes are expressed ubiquitously in transgenic mice, under a powerful promoter, their coat colour is also black (despite being genetically agouti). This demonstrates that an inappropriately high, level of $\beta$-defensin can result in promiscuous receptor binding in vivo. A further example of promiscuous receptor binding and neutral antagonist behaviour is the ability of recombinant HBD3 (at $5,10,20$, and $40 \mu \mathrm{g} / \mathrm{ml}$ ) to compete with stromal-derived factor 1 (SDF-1), in a structural and charge dependent manner, for cellular binding to CXCR4, without increasing calcium mobilization or chemotaxis $(84,85)$. CXCR4, also known as fusin, is used for HIV entry into CD4+ T cells. However, copy number increase of the HBD3 gene does not associate with protection against HIV (86).

\section{BETA-DEFENSINS AS RESOLVERS}

In contrast to alarmin activity (see section Beta-Defensins as Alarmins) we use the term "resolvers" here to describe the antiinflammatory pro-resolving activity of $\beta$-defensins.

\section{Innate Suppression}

As discussed above, in the presence of defensins, some pattern recognition receptors increase the response to stimulation. However, exposure to TLR4 ligands (such as LPS) or CD40 activation in the presence of HBD3 $(1 \mu \mathrm{M})$ results in a decrease in cytokine responses in primary macrophages $(87,88)$. This anti-inflammatory effect was also observed in vivo, where serum from mice displayed a decrease in proinflammatory cytokines following injection of LPS and HBD3 peptide compared to LPS alone (87). This suppression was independent of defensin binding to TLR4 or LPS and could be observed even if the peptide was added up to an hour after the LPS. HBD3 suppressed cytokine and type I interferon production through the MyD88 and TICAM1 pathways, respectively (89). Exposure to HBD3 and LPS compared to LPS alone showed reduced transcription of many genes associated with TLR4 activation, while others were increased, including TLR2-demonstrating that this was not simply an inhibition of all signalling downstream of the receptor. HBD3 alone had no effect on macrophage transcription. Further pathway analysis, using InnateDB, showed that many LPS-induced proinflammatory signalling pathways were downregulated when HBD3 was also present but that metabolism, classical complement activation and Fc $\gamma$ R-dependent phagocytosis were upregulated (74). The antiinflammatory effect of HBD3 on macrophages was also seen in the acute inflammatory cytokine response to Porphyromonas gingivalis in vitro and in vivo (88). Indeed, mice with an exaggerated response to $P$. gingivalis LPS (ApoE -/-) showed an increase in CCL2, TNF- $\alpha$, IL-6, and NO levels at $2 \mathrm{~h}-$ but HBD3 (10 $\mu \mathrm{g} /$ mouse) could suppress this. The authors also report an increase in Arginase 1, a key marker of mouse alternatively activated macrophages (AMM or termed $\mathrm{M} 2$ ), possibly indicating a change in cellular polarisation as a consequence of defensin exposure.

A similar inflammation suppressive effect has also been recently observed with $\mathrm{HBD} 2$, which reduced $\mathrm{TNF} \alpha$ and IL$1 \beta$ secretion from dendritic cells in human peripheral blood mononuclear cells exposed to LPS. The effect was lost in the presence of a CCR2 inhibitor. When HBD2 was delivered systemically to a variety of mouse models of inflammatory bowel disease, the colitis was reduced to a level comparable to steroids and anti-TNF $\alpha$ (90). In addition, in the infected cornea of mice, silencing of the murine orthologues of HBD2 and 3 resulted in increased production of proinflammatory cytokines, with a simultaneous increase in bacterial load (91). The effect on bacterial load is postulated to be due to the defensins [at low concentration of $1 \mu \mathrm{g} / \mathrm{ml}(0.2 \mu \mathrm{M})]$ inhibiting macrophage autophagy and in this way increasing phagocytic receptor expression leading to intracellular killing of the Pseudomonas aeruginosa (92). All these studies indicate that, under specific infections scenarios, defensins are capable of contributing to antiinflammatory response, or at least a rebalancing of the nature of the cellular response.

\section{Adaptive Suppression}

In addition to effects on innate responses to infectious and inflammatory stimuli, defensins have also been shown to have suppressive effects on adaptive immunity. UVB radiation induces Defb14 production in keratinocytes while DEFB14 peptide injection into mice suppressed contact hypersensitivity, but this was shown to involve the induction of antigen-specific regulatory $\mathrm{T}$ cells (Tregs), rather than the UV suppression pathway (93). The HBD3 peptide [at $10 \mu \mathrm{g} / \mathrm{ml}(2 \mu \mathrm{M})]$ has a demonstrated capacity to alter CD4+ CD25- T cells, from a non-regulatory phenotype towards a regulatory phenotype with expression of both the characteristic regulatory $\mathrm{T}$ cell (Treg) transcription factor (FoxP3) and cytotoxic T-lymphocyteassociated protein 4 (CTLA4), a protein which downregulates immune responses (94). Treatment of CD4+CD25- cells with DEFB14 resulted in reduction in methylation of the Foxp3 promoter compared to cells without DEFB14 (and closer to the level seen in Tregs) which correlated with an increase in FoxP3 expression. Additionally, treatment with DEFB14 before, or after, the induction of experimental autoimmune encephalomyelitis (mouse model of multiple sclerosis), was found to ameliorate the disease, with less 
central nervous system inflammation and decreased levels of proinflammatory cytokines and cytotoxic $\mathrm{T}$ cells (94). The beneficial effect was lost upon depletion of regulatory $\mathrm{T}$ cells. These observations were attributable to an increase in suppressive CD4+ T cells, possibly through a change in cellular polarisation but the mechanism underpinning defensin-induced modulation of $\mathrm{CD} 4+\mathrm{T}$ cells to a regulatory phenotype requires further investigation.

Further evidence of immune suppression by HBD3 (or DEFB14) arises from studies of diabetes. $\beta$-defensins were shown to be expressed in endocrine cells in both the human and mouse pancreas (95). DEFB14 treatment of non-obese diabetic mice was found to dampen the autoimmune response and to reduce subsequent diabetes development. This disease limitation was shown to be due to DEFB14 increasing proliferation of pancreatic B cells, expressing the regulatory cytokine IL-4 and the repair cytokine active TGF $\beta$, which enabled polarisation of alternatively activated macrophages and a subsequent increase in Treg cells. This immune modulating pathway was believed to account for the reduction in autoimmune inflammation, with DEFB14 playing an integral role possibly through induction of TLR2.

\section{Wound Healing Resolution}

In addition to roles in innate and adaptive immune responses, $\beta$-defensins have been found to play important roles in resolution of damage pathways, via effects on wound healing. Characterising chronic wounds, $\beta$-defensin expression is found to be decreased in diabetic ulcers (96). This is thought to contribute to increased infection and also to a lack of wound healing, through mechanisms such as stimulating the migration of fibroblasts, as well as the proliferation of keratinocytes $(97,98)$. HBD2 also is reported to promote wound healing of intestinal cells in vitro (99) and in vivo by stimulating keratinocyte migration and proliferation in rats (100). The physiological significance of these findings are demonstrated in mice with Defb14 deletion, which display delayed wound healing in vivo, with significantly increased wound area, delayed epithelialisation and an altered wound microbiota (97). In addition, there is an observed increase in classically activated macrophages in these wound sites and a trend towards decreased alternatively activated macrophages, together with an increased bacterial load in the skin (97). This implies that DEFB14 is important in wound repair and that insufficient peptide expression may reduce wound healing as a consequence of inappropriate macrophage polarisation (section Innate Suppression) and/or alteration in the ratio of local cellular populations. Macrophages are key in wound repair and can be central in the process by promoting a resolution of inflammation leading to tissue repair. CCL2, the major macrophage chemoattractant, can reverse the impaired wound healing in diabetic mice (101) and HBD3 can chemoattract macrophages through CCR2 and also modulate pattern recognition receptors relevant to wound repair (102, 103). As with all resolution milieu, successful wound healing will be multifactorial, but these data suggest that $\beta$-defensins are likely to contribute.

\section{HUMAN DISEASE ASSOCIATION}

Given the range of roles that $\beta$-defensins display, it is not surprising that their expression and influence are demonstrably intertwined into various disease states. For the sake of examining $\beta$-defensins in human non-infectious disease, however, discussion will be based on the main expression sites, epithelial cells, predominantly localised to the gut and skin. We will not be addressing their influence on cancer, although the involvement of $\beta$-defensins in cancer also demonstrates dichotomous behaviour. For example, their expression can be increased or decreased in tumours, their influence can be to promote or suppress, and these effects can be dependent upon the specific defensin peptide, the cancer type and the cells involved [for an excellent, recent review of the literature see (104)].

In addition to the complex, localised environmental influences that dictate $\beta$-defensin function, there is the issue of copy number variation, as mentioned previously. Six $\beta$-defensin genes (DEFB4, DEFB103, DEFB104, DEFB105, DEFB106, DEFB107), and the $\beta$-defensin related gene SPAG11, are present at chromosome 8 p23.1, at two loci $5 \mathrm{Mb}$ apart and are hyper $\mathrm{CNV}$, changing through unequal crossing over at the rate of $\sim 0.7 \%$ per gamete (25). Worldwide, the average copy number of this unit is four, although copy numbers range from two to twelve (this does not occur in all species, with mice being an example of no copy number variation). The variation in these genes, combined with the alteration in expression based on localised stimulation, gives a large range of expression for these peptides, with overall inflammation in disease considered a stronger influence on expression than copy number $(5,105)$. The link between the level of expression of $\beta$-defensins and disease is discussed below.

\section{Psoriasis}

Indication that $\beta$-defensin copy number associates with disease development is evident in psoriasis. Psoriasis is a disease principally characterized by skin plaques, commonly found on the elbows, knees and trunk. Psoriatic lesions are described as sites of chronic skin inflammation with thickened, hyperplastic epidermis, increased vascularity and immune cell invasion. Lesions display overexpression of several inflammatory peptides and cytokines. The overexpression of these local cytokines (such as TNF $\alpha$, IFN $\gamma$ and IL-1) leads to increased expression of $\beta$ defensins within the lesions $(106,107)$, to a degree that allowed both HBD2 and HBD3 to be first isolated from psoriatic scales. In addition, there is a significant, replicated association between more than four copy numbers of the $\beta$-defensin seven gene repeat unit and psoriasis occurrence $(108,109)$. This goes beyond localised disease region expression, however, as serum levels of HBD2 correlate with copy number, both in normal individuals and disease state (where increase in serum HBD2 also correlates with psoriasis severity) (110) and HBD3 expression is increased in both normal and lesional skin of psoriasis patients, possibly adding to the reduced bacterial burdens in lesions compared with those in atopic dermatitis (see below) (111). It is not clear how increased $\beta$-defensin expression contributes to disease aetiology, but, as mentioned above, $\beta$-defensins HBD3 and 2 have 


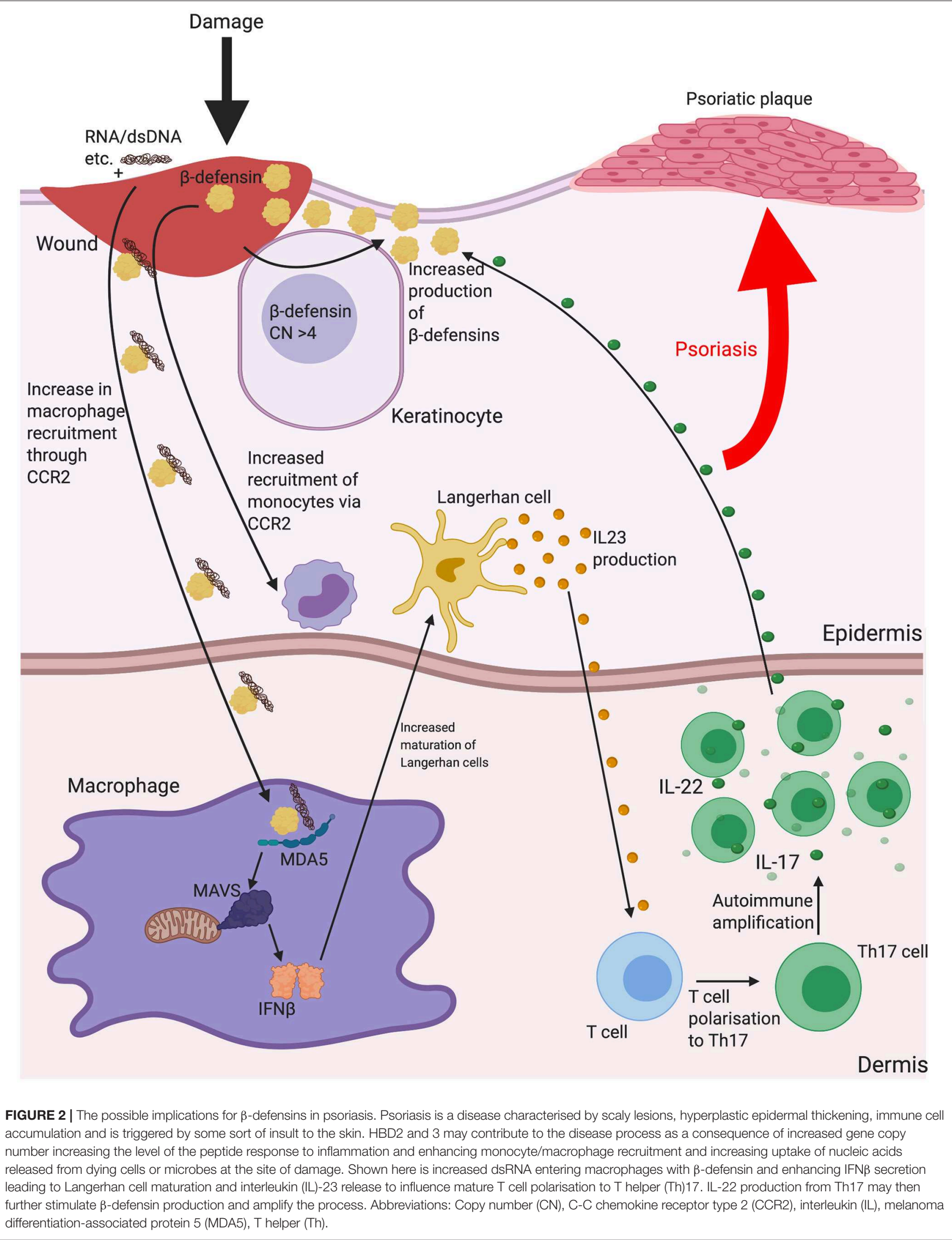


been shown to increase the Interferon- $\alpha$ response to DNA via TLR9 and the Interferon- $\beta$ response to RNA through stimulation of the MDA5/MAVS pathway (see section Innate Triggers). HBD2 has been shown to be evident in the same dermal compartment as $\mathrm{pDC}$ in psoriatic skin, leading to a hypothesis that this peptide may be instrumental in breaking tolerance to self-DNA following infection or damage (67). Injection of CpG DNA:HBD3-defensin complexes subcutaneously in mice, increased epidermal hyperplasia and both neutrophil and lymphocyte recruitment at $24 \mathrm{~h}$ (66), supporting this hypothesis. Psoriasis is a Th17 predominated disease and effective treatment with UV irradiation is linked to suppression of type I Interferon and Th17 cells (112). In addition, psoriasis can be induced in multiple sclerosis patients using IFN $\beta$ therapy (113). The current effective treatments for psoriasis are biologics against IL-17 production or IL-12p40 (subunit common to both Il12 and IL-23), to limit Th17 cell production and action. Of note, IL-22 is expressed by Th17 cells, which triggers $\beta$ defensin expression (95). Interestingly, individuals with missense variants in Human MDA5 gene (IFIH1) are protected from psoriasis (114) and gain of function MDA5 mutations have related type I interferonopathy with musculoskeletal disease that includes psoriasis (115). These lines of evidence strongly support the involvement of Interferon $\beta$ in psoriasis and the genetic link between increased $\beta$-defensin CNV and psoriasis may be due to an increase in $\beta$-defensin expression having a functional consequence in the responses to dsRNA released from wounds, via MDA5/MAVS signalling and production of IFN $\beta$ (see Figure 2).

\section{Atopic Dermatitis}

Another skin disease associated with $\beta$-defensin expression is atopic dermatitis $(\mathrm{AD})$ [for a more extensive review of the associations between $\beta$-defensin and $\mathrm{AD}$ see Chieosilapatham et al. (116)]. AD is another chronic inflammatory skin disease, characterised by itchy, inflamed lesions across a range of different body sites (117). In comparison with psoriatic plaques, $A D$ lesions have a decrease in expression of these $\beta$-defensins (118) with induction of peptide levels found to be impaired for the level of inflammation. This has not been found to be related to copy number variation, however, and is instead due to the local Th2-skewed cytokine milieu and thus focused inhibition of $\beta$-defensin expression (119). Despite these lesional differences, $\mathrm{HBD} 2$, but not HBD3, is found to be increased in $\mathrm{AD}$ serum (120). Reduced defensins at the sites of disease may contribute to the pathology of $\mathrm{AD}$ in a number of ways, including the increase in lesional skin infections that are characteristic of the condition (121) (see Figure 3). In addition to the direct bactericidal properties of some of these peptides, it has been shown that HBD3 can increase expression of tight junction components in keratinocytes and improve barrier function (122). Further, we recently demonstrated that some $\beta$-defensins, such as $\mathrm{HBD} 2$, are able to inhibit the barrier-damaging effects of bacterial proteases, such as from the common AD lesional pathogen Staphylococcus aureus, which can contribute to this disease, in which loss of barrier integrity is critical (123). The mechanism of this is not yet fully elucidated and is subject to further investigation.

\section{Inflammatory Bowel Disease}

In addition to inflammatory disorders of the skin, $\beta$-defensin expression has been shown to be altered in chronic inflammatory disorders of the gut. Unlike the skin, however, $\beta$-defensins are not the key AMP type in the gastrointestinal tract. Instead, the most abundantly expressed AMP group is the human $\alpha$-defensins, including human defensin 5 (HD5) and human defensin 6 (HD6), which are constitutively expressed by Paneth cells located at the base of the crypts of Luberkühn (unique to the small intestine) $(124,125)$. As well as being known to have antibacterial (HD5) and antiviral (HD6) activities (126), these peptides are known to be chemoattractive for naïve and memory CD4+ $\mathrm{T}$ lymphocytes, as well as macrophages and mast cells (127). Similarly to their $\beta$-defensin cousins, they are also linked chronic inflammatory disorders, with decreased levels of both HD5 and HD6 being demonstrated in ileal Crohn's disease (affecting the upper parts of the intestine) (128). It is thought that this lack of expression allows for increased pathogenic bacteria and therefore worsening of pathology (129).

While $\alpha$-defensin are present in Paneth cell granules in the upper parts of the intestine, $\beta$-defensin expression is conducted by enterocytes, which are the most abundant epithelial cell lineage in both the small and large intestine (130). Enterocytes of the colon express HBD1 constitutively, with HBD2 being induced by TLR stimulation (131). HBDs can also be induced in the gastric mucosa, when faced with bacterial challenge (132) and expression of $\beta$-defensins is shown to be altered in chronic inflammatory bowel diseases (IBD) of the gut. Comparably to the relationship between $\beta$ defensin levels and different chronic inflammatory disorders of the skin, there appears to be a discrepancy in activity in different IBD disorders of the gut. Patients who suffer from Crohn's disease present a decrease in HBD2 $\beta$-defensin levels, and a concomitant decrease in the gene copy repeating unit suggested as a factor for predisposition to the disease $(133,134)$. HBD2 has recently been delivered subcutaneously to mice with induced models of intestinal bowel disease and successfully reduced the level of inflammation (90). In opposition to Crohn's disease, patients with ulcerative colitis (a disease of the colon) have a highly increased expression of HBD2, although not HBD1 (135). This has been argued to be due to changes in localised cytokine milieu, rather than variations in copy number. Aldhous et al. demonstrate that DEFB4 mRNA and HBD2 protein levels varied upon stimulation with inflammatory cytokines in samples from IBD patients, independent of variations in HBD2 copy number (105). In this case, the influence of copy number variation is overridden by the impact of the local inflammatory environment. However, this is in the context of the high level of variation in defensin expression from one region of the gut to another, which is also in combination with differences between biopsy location and inflamed vs. non-inflamed areas of the bowel (105). This requires further study and the influence of the microbiota on defensin 


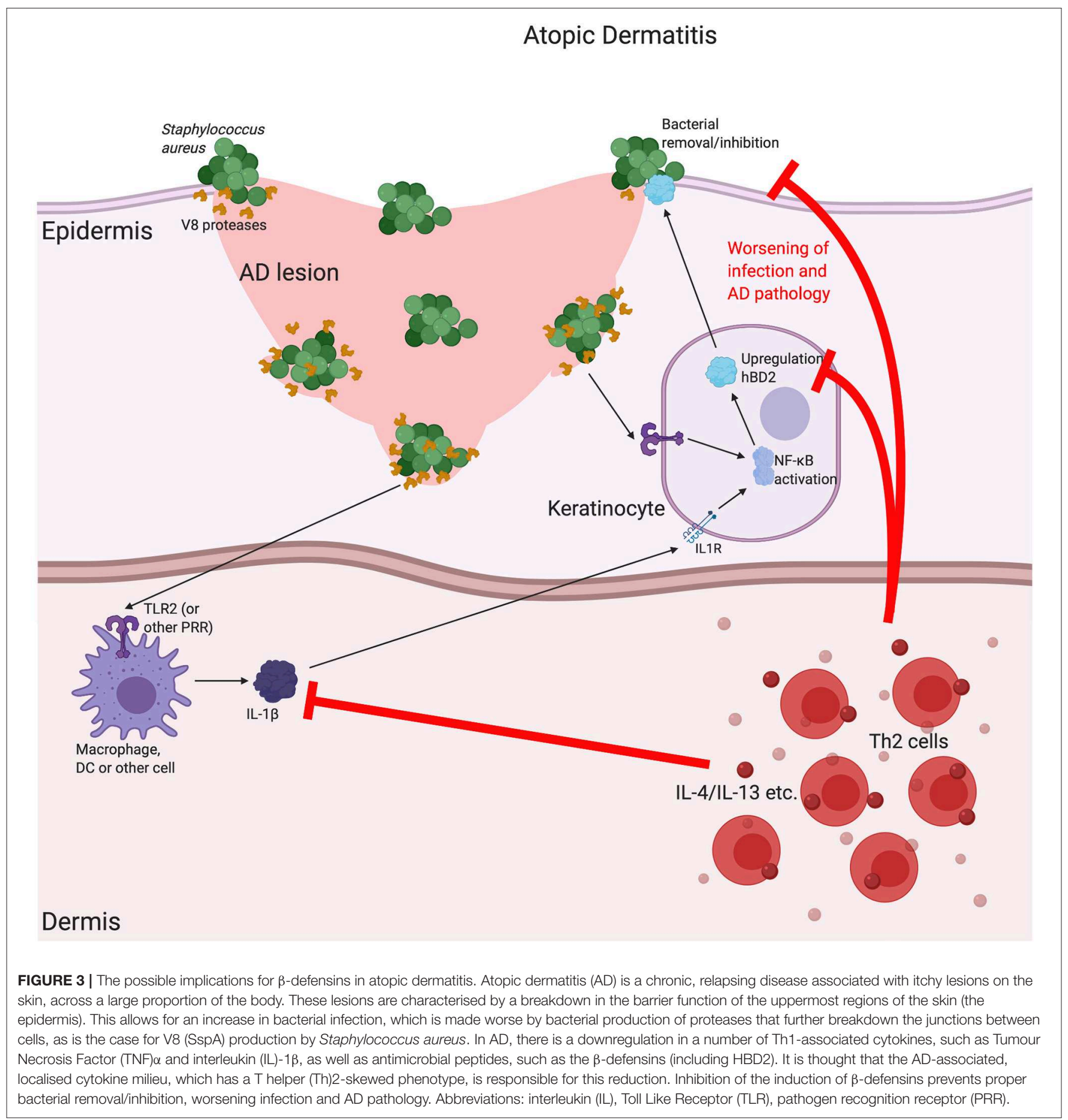

expression and defensin expression on microbiota composition needs clarification.

\section{CONCLUSION}

It is clear that $\beta$-defensins are not only AMPs, and their ability to change the behaviour of eukaryotic (particularly immune) cells at similar concentrations as those required to kill pathogens is intriguing. Here we have described the increasing body of research that has revealed the ability of $\beta$-defensins to behave in a dichotomous way with respect to inflammation. Under certain conditions they behave as alarmins and yet under other conditions they are suppressors of inflammation. The difference in effect does not seem to be due to the levels of peptide. As the Dorin lab has shown, the same peptide preparation 
on human and mouse primary macrophages can suppress or increase inflammatory signalling, dependent on which PRR ligand is used. The charged nature of $\beta$-defensins is likely to be important in how it interacts with a variety of molecules and may explain why HBD3, with its high charge, consistently gives the most potent responses. Blocking receptors, binding to nucleic acids to enhance receptor engagement, and inducing chemoattraction, are all likely to be driven by the cationic and amphipathic nature of the peptides. At higher levels (above $2 \mu \mathrm{M}) \beta$-defensins certainly have a cytotoxic effect, but this may be supraphysiological. During infection, rapid killing, detection and innate response are essential; therefore, in this regard, high HBD3 copy number and potentiation of PRR may be beneficial. However, an undesirable effect of increased copy number of the defensin cluster (and concomitant increase in expression of defensin peptides) may be over stimulation of PRRs leading to exuberant production of type I interferons. This double-edged sword may provide protection against pathogens in the short term, but in the longer term contribute to the development of psoriasis in individuals with an increased copy number of the $\beta$-defensin cluster.

In vivo experiments are the most compelling to attribute function, because other cationic host defence peptides will also play a part, as some have synergistic actions and come from recruited, as well as resident cells at the site of injury. The in vivo evidence that DEFB14 or HBD3 can increase the inflammatory state of mouse skin but increase wound healing and suppress

\section{REFERENCES}

1. Mookherjee N, Anderson MA, Haagsman HP, Davidson DJ. Antimicrobial host defence peptides: functions and clinical potential. Nat Rev Drug Discov. (2020) 19:311-32. doi: 10.1038/s41573-019-0058-8

2. Shafee TM, Lay FT, Hulett MD, Anderson MA. The defensins consist of two independent, convergent protein superfamilies. Mol Biol Evol. (2016) 33:2345-56. doi: 10.1093/molbev/msw106

3. Montero-Alejo V, Corzo G, Porro-Suardíaz J, Pardo-Ruiz Z, Perera E, Rodríguez-Viera L, et al. Perdomo-Morales: Panusin represents a new family of $\beta$-defensin-like peptides in invertebrates. Dev Comp Immunol. (2017) 67:310-321. doi: 10.1016/j.dci.2016.09.002

4. Mitchell ML, Shafee T, Papenfuss AT, Norton RS. Evolution of cnidarian trans-defensins: sequence, structure and exploration of chemical space. Proteins. (2019) 87:551-60. doi: 10.1002/prot. 25679

5. Hollox EJ, Abujaber R. Evolution and diversity of defensins in vertebrates. In: Evolutionary Biology: Self/Nonself Evolution, Species and Complex Traits Evolution, Methods and Concepts. Cham: P. P. Springer (2017). p. 27-50. doi: 10.1007/978-3-319-61569-1_2

6. Beckloff NG. Diamond: Computational analysis suggests beta-defensins are processed to mature peptides by signal peptidase. Protein Pept Lett. (2008) 15:536-40. doi: 10.2174/092986608784567618

7. Semple C, A, Maxwell A, Gautier P, Kilanowski F, M, et al. Dorin: The complexity of selection at the major primate beta-defensin locus. BMC Evol Biol. (2005) 5:32. doi: 10.1186/1471-2148-5-32

8. Yudin AI, Treece CA, Tollner TL, et al. Cherr: The carbohydrate structure of DEFB126, the major component of the cynomolgus Macaque sperm plasma membrane glycocalyx. J Membr Biol. (2005) 207:11929. doi: 10.1007/s00232-005-0806-z

9. Schutte BC, Mitros JP, Bartlett JA, Walters JD, Jia HP, Welsh MJ, et al. Discovery of five conserved beta -defensin gene clusters using a development of autoimmune diabetes are clear demonstrations of the dichotomy of the influence of $\beta$-defensins on mammalian cells. The influence of increased $\beta$-defensin expression in psoriasis and reduced expression in atopic dermatitis may reflect the different disease environments; in this case increased copy number in psoriasis may be the causative factor. This is an exciting area of research and further clarification of the factors that give rise to the type of response $\beta$-defensins encourage is important for therapeutic strategies.

\section{AUTHOR'S NOTE}

We apologize to our colleagues whose work we were unable to cite due to space limitation.

\section{AUTHOR CONTRIBUTIONS}

Manuscript conceived, researched and written by JS and JD, with additional interpretation, writing and editing by DD.

\section{FUNDING}

JD was supported by University of Edinburgh and Medical Research UK grant award MR/P02338X/1. JS and DD were funded by British Skin Foundation Large Grant Award 026/s/17, DD was also funded by Action Medical Research Grant GN2703 and Chief Scientist Office Grant TCS/18/02. computational search strategy. Proc Natl Acad Sci USA. (2002) 99:212933. doi: 10.1073/pnas.042692699

10. Patil AA, Cai Y, Sang Y, Blecha FG. Zhang: Cross-species analysis of the mammalian $\beta$-defensin gene family: presence of syntenic gene clusters and preferential expression in the male reproductive tract. Physiol Genom. (2005) 23:5-17. doi: 10.1152/physiolgenomics.00104.2005

11. Shanahan MT, Tanabe H, Ouellette AJ. Strain-specific polymorphisms in Paneth cell $\alpha$-defensins of C57BL/6 mice and evidence of vestigial myeloid $\alpha$-defensin pseudogenes. Infect Immun. (2011) 79:459-73. doi: 10.1128/IAI.00996-10

12. Lilue J, Shivalikanjli A, Adams DJ, Keane TM. Mouse protein coding diversity: What's left to discover? PLoS Genet. (2019) 15:e1008446. doi: 10.1371/journal.pgen.1008446

13. Batista da Cunha D, Pupo Silvestrini AV, Gomes da Silva AC, Maria de Paula Estevam D, Pollettini FL, de Oliveira Navarro J, et al. Mechanistic insights into functional characteristics of native crotamine. Toxicon. (2018) 146:1-12. doi: 10.1016/j.toxicon.2018.03.007

14. Meng L, Xie Z, Zhang Q, Li Y, Yang F, Chen Z, et al. Scorpion potassium channel-blocking defensin highlights a functional link with neurotoxin. J Biol Chem. (2016) 291:7097-106. doi: 10.1074/jbc.M115.680611

15. Kudryashova E, Quintyn R, Seveau S, Lu W, Wysocki V, Kudryashov DS. Kudryashov: Human defensins facilitate local unfolding of thermodynamically unstable regions of bacterial protein toxins. Immunity. (2014) 41:709-21. doi: 10.1016/j.immuni.2014.10.018

16. Kudryashova E, Koneru PC, Kvaratskhelia M, Strömstedt AA, Lu W, Kudryashov DS. Kudryashov: thermodynamic instability of viral proteins is a pathogen-associated molecular pattern targeted by human defensins. Sci Rep. (2016) 6:32499. doi: 10.1038/srep32499

17. Yang W, Feng J, Xiang F, Xie Z, Zhang G, Sabatier J, et al. Wu: Endogenous animal toxin-like human $\beta$-defensin 2 inhibits own $\mathrm{K}(+)$ channels through interaction with channel extracellular pore region. Cell Mol Life Sci. (2015) 72:845-53. doi: 10.1007/s00018-014-1715-z 
18. Prasad SV, Fiedoruk K, Daniluk T, Piktel E, Bucki R. Expression and function of host defense peptides at inflammation sites. Int J Mol Sci. (2019) 21. doi: 10.3390/ijms21010104

19. Fruitwala S, El-Naccache D, W TL. Chang: multifaceted immune functions of human defensins and underlying mechanisms. Semin Cell Dev Biol. (2019) 88:163-72. doi: 10.1016/j.semcdb.2018.02.023

20. Rodriguez-Jimenez FJ, Krause A, Schulz S, Forssmann WG, Conejo-Garcia JR, Schreeb R, et al. Motzkus: distribution of new human beta-defensin genes clustered on chromosome 20 in functionally different segments of epididymis. Genomics. (2003) 81:175-83. doi: 10.1016/S0888-7543(02)00034-4

21. Thimon V, Koukoui O, Calvo E, Sullivan R. Region-specific gene expression profiling along the human epididymis. Mol.Hum.Reprod. (2007) 13:691704. doi: 10.1093/molehr/gam051

22. Tollner TL, Venners SA, Hollox EJ, Yudin AI, Liu X, Tang G, et al. A Common mutation in the defensin DEFB126 causes impaired sperm function and subfertility. Sci Transl Med. (2011) 3:92ra65. doi: 10.1126/scitranslmed.3002289

23. Zhou YS, Webb S, Lettice L, Tardif S, Kilanowski F, Tyrrel C, et al. Partial deletion of chromosome $8 \quad \beta$-defensin cluster confers sperm dysfunction and infertility in male mice. PLoS Genet. (2013) 9:e1003826. doi: 10.1371/journal.pgen.1003826

24. Zhang C, Zhou Y, Xie S, Yin Q, Tang C, Ni Z, et al. Zhang: CRISPR/Cas9mediated genome editing reveals the synergistic effects of $\beta$-defensin family members on sperm maturation in rat epididymis. FASEB J. (2018) 32:135463. doi: 10.1096/fj.201700936R

25. Abu BS, Hollox EJ, Armour JA. Allelic recombination between distinct genomic locations generates copy number diversity in human beta-defensins. Proc Natl Acad Sci USA. (2009) 106:853-8. doi: 10.1073/pnas.0809073106

26. Yarbrough VL, Winkle S, Herbst-Kralovetz MM. Antimicrobial peptides in the female reproductive tract: a critical component of the mucosal immune barrier with physiological and clinical implications. Hum Reprod Update. (2015) 21:353-77. doi: 10.1093/humupd/dmu065

27. Harder J, Bartels J, Christophers E, Schröder JM. Isolation and characterization of human $\beta$-defensin-3, a novel human inducible peptide antibiotic. J Biol Chem. (2001) 276:5707. doi: 10.1074/jbc.M0085 57200

28. Bals R, Wang X, Wu Z, Freeman T, Bafna V, Zasloff M. Wilson: human betadefensin 2 is a salt-sensitive peptide antibiotic expressed in human lung. $J$ Clin Invest. (1998) 102:874. doi: 10.1172/JCI2410

29. Hiratsuka T, Nakazato M, Date Y, Ashitani Minematsu T, Chino NS. Matsukura: identification of human $\beta$-defensin-2 in respiratory tract and plasma and its increase in bacterial pneumonia. Biochem Biophys Res Commun. (1998) 249:943. doi: 10.1006/bbrc.1998.9239

30. Mathews M, Jia HP, Guthmiller JM, Losh G, Graham S, Johnson GK, et al. Production of $\beta$-defensin antimicrobial peptides by the oral mucosa and salivary glands. Infect Immun. (1999) 67:2740. doi: 10.1128/IAI.67.6.2740-2745.1999

31. Ryan LK, Diamond G. Diamond: modulation of human $\beta$-defensin-1 production by viruses. Viruses. (2017) 9:153-63. doi: 10.3390/v9060153

32. Sørensen OE, Thapa DR, Rosenthal A, Liu L, Roberts AA, Ganz T. Differential regulation of beta-defensin expression in human skin by microbial stimuli. J Immunol. (2005) 174:48709. doi: 10.4049/jimmunol.174.8.4870

33. Duits LA, Nibbering PH, van Strijen E, Vos J, Mannesse-Lazeroms SP, van Sterkenburg MA, et al. Rhinovirus increases human beta-defensin-2 and-3 mRNA expression in cultured bronchial epithelial cells. FEMS Immunol Med Microbiol. (2003) 38:59-64. doi: 10.1016/S0928-8244(03)00106-8

34. Braff $\mathrm{MH}$, Bardan A, Nizet V, Gallo RL. Cutaneous defense mechanisms by antimicrobial peptides. J Invest Dermatol. (2005) 125:9. doi: 10.1111/j.0022-202X.2004.23587.x

35. Kao CY, Chen Y, Thai P, Wachi S, Huang F, Kim C, et al. IL-17 markedly up-regulates beta-defensin-2 expression in human airway epithelium via JAK and NF-kappaB signaling pathways. J Immunol. (2004) 173:348291. doi: 10.4049/jimmunol.173.5.3482

36. Mulcahy ME, Leech JM, Renauld JC, Mills KH, McLoughlin RM. McLoughlin: Interleukin-22 regulates antimicrobial peptide expression and keratinocyte differentiation to control Staphylococcus aureus colonization of the nasal mucosa. Mucosal Immunol. (2016) 9:1429-41. doi: 10.1038/mi.2016.24

37. Wang W, Qu X, Dang X, Shang D, Yang L, Li Y, et al. Chang: Human $\beta$ defensin-3 induces IL-8 release and apoptosis in airway smooth muscle cells. Clin Exp Allergy. (2017) 47:1138-49. doi: 10.1111/cea.12943

38. Groth M, Wiegand C, Szafranski K, Huse K, Kramer M, Rosenstiel P, et al. Platzer: both copy number and sequence variations affect expression of human DEFB4. Genes Immun. (2010) 11:458-66. doi: 10.1038/gene.2010.19

39. Hardwick RJ, Machado LR, Zuccherato LW, Antolinos S, Xue Y, Shawa N, et al. Hollox: A worldwide analysis of beta-defensin copy number variation suggests recent selection of a high-expressing DEFB103 gene copy in East Asia. Hum Mutat. (2011) 32:743-50. doi: 10.1002/humu.21491

40. Wu Z, Hoover DM, Yang D, Boulegue C, Santamaria F, Oppenheim JJ, et al. Engineering disulfide bridges to dissect antimicrobial and chemotactic activities of human beta-defensin 3. Proc Natl Acad Sci USA. (2003) 100:8880-5. doi: 10.1073/pnas.1533186100

41. Schibli DJ, Hunter HN, Aseyev V, Starner T, Wiencek JM, McCray $\mathrm{PB}$, et al. The solution structures of the human beta-defensins lead to a better understanding of the potent bactericidal activity of HBD3 against Staphylococcus aureus. J Biol Chem. (2002) 277:8279-89. doi: 10.1074/jbc.M108830200

42. Hoover DM, Rajashankar KR, Blumenthal R, Puri A, Oppenheim JJ, Chertov O, et al. Lubkowski: The structure of human beta-defensin-2 shows evidence of higher order oligomerization. J Biol Chem. (2000) 275:329118. doi: 10.1074/jbc.M006098200

43. Schroeder BO, Wu Z, Nuding S, Groscurth S, Marcinowski M, Beisnep J, et al. Reduction of disulphide bonds unmasks potent antimicrobial activity of human beta-defensin 1. Nature. (2011) 469:419-23. doi: 10.1038/nature09674

44. Schibli DJ, Hunter HN, Aseyev V, Starner T, Wiencek, JM, McCray $\mathrm{PB}$ Jr, et al. The solution structures of the human beta-defensins lead to a better understanding of the potent bactericidal activity of HBD3 against Staphylococcus aureus. J Biol Chem. (2002) 277:827989. doi: 10.1074/jbc.M108830200

45. Yang D, Oppenheim JJ. Antimicrobial proteins act as "alarmins" in joint immune defense. Arthritis Rheum. (2004) 50:3401-3. doi: 10.1002/art.20604

46. Bianchi ME. DAMPs, PAMPs and alarmins: all we need to know about danger. J Leukoc Biol. (2007) 81:1-5. doi: 10.1189/jlb.0306164

47. Yang D, Wei F, Tewary P, Howard O, M JJ. Oppenheim: Alarmin-induced cell migration. Eur J Immunol. (2013) 43:1412-8. doi: 10.1002/eji.201243138

48. Dürr MA. Peschel: chemokines meet defensins: the merging concepts of chemoattractants and antimicrobial peptides in host defense. Infect Immun. (2002) 70:6515-7. doi: 10.1128/IAI.70.12.6515-6517.2002

49. Yang D, Chen Q, Hoover DM, Staley P, Tucker KD, Lubkowski J, et al. Many chemokines including CCL20/MIP-3alpha display antimicrobial activity. $J$ Leukoc Biol. (2003) 74:448-55. doi: 10.1189/jlb.0103024

50. Seo ES, Blaum BS, Vargues T, De Cecco M, Deakin JA, Lyon M, et al. Interaction of human beta-defensin 2 (HBD2) with glycosaminoglycans. Biochemistry. (2010) 49:10486-95. doi: 10.1021/bi1011749

51. Yang D, Chertov O, Bykovskaia SN, Chen Q, Buffo M, Shogan $\mathrm{J}$, et al. Oppenheim: Beta-defensins: linking innate and adaptive immunity through dendritic and T cell CCR6. Science. (1999) 286:525-8. doi: 10.1126/science.286.5439.525

52. Niyonsaba F, Ogawa HI. Nagaoka: Human beta-defensin2 functions as a chemotactic agent for tumour necrosis factor-alpha-treated human neutrophils. Immunology. (2004) 111:273-81. doi: 10.1111/j.0019-2805.2004.01816.x

53. Hoover DM, Boulegue C, Yang D, Oppenheim JJ, Tucker K, Lu W, et al. Lubkowski: the structure of human MIP-3alpha /CCL20: Linking antimicrobial and CCR6 receptor binding activities with human beta defensins. J Biol Chem. (2002) 277:37647-54. doi: 10.2210/pdb1m8a/pdb

54. Taylor K, Rolfe M, Reynolds N, Kilanowski F, Pathania U, Clarke D, et al. Dorin: Defensin-related peptide 1 (Defr1) is allelic to Defb8 and chemoattracts immature DC and CD4+ T cells independently of CCR6. Eur J Immunol. (2009) 39:1353-60. doi: 10.1002/eji.200838566

55. Taylor K, Clarke DJ, McCullough B, Chin W, Seo E, Dorin D, et al. Analysis and separation of residues important for the chemoattractant and 
antimicrobial activities of beta -defensin 3. J Biol Chem. (2008) 283:66319. doi: 10.1074/jbc.M709238200

56. Soruri A, Grigat J, Forssmann U, Riggert J, Zwirner J. beta-Defensins chemoattract macrophages and mast cells but not lymphocytes and dendritic cells: CCR6 is not involved. Eur J Immunol. (2007) 37:247486. doi: 10.1002/eji.200737292

57. Rohrl J, Yang D, Oppenheim J, Hehlgans JT. Human beta-defensin 2 and 3 and their mouse orthologs induce chemotaxis through interaction with CCR2. J Immunol. (2010) 184:6688-94. doi: 10.4049/jimmunol.0903984

58. Jin G, Kawsar HI, Hirsch SA, Zeng C, Jia X, Feng Z, et al. An antimicrobial peptide regulates tumor-associated macrophage trafficking via the chemokine receptor CCR2, a model for tumorigenesis 1. PLOS ONE. (2010) 5:e10993. doi: 10.1371/journal.pone.0010993

59. Suarez-Carmona M, Hubert P, Gonzalez A, Duray A, Roncarati P, Erpicum C, et al. $\Delta$ Np63 isoform-mediated $\beta$-defensin family up-regulation is associated with (lymph)angiogenesis and poor prognosis in patients with squamous cell carcinoma. Oncotarget. (2014) 5:1856-68. doi: 10.18632/oncotarget.1819

60. Niyonsaba F, Ushio H, Nakano N, Ng W, Sayama K, Hashimoto $\mathrm{K}$, et al. Antimicrobial peptides human beta-defensins stimulate epidermal keratinocyte migration, proliferation and production of proinflammatory cytokines and chemokines 1 . J Invest Dermatol. (2007) 127:594-604. doi: 10.1038/sj.jid.5700599

61. Funderburg N, Lederman MM, Feng Z, Drage MG, Jadlowsky J, Harding $\mathrm{CV}$, et al. Human $\beta$-defensin-3 activates professional antigen-presenting cells via Toll-like receptors 1 and 2. Proc Natl Acad Sci USA. (2007) 104:186315. doi: 10.1073/pnas.0702130104

62. Funderburg NT, Jadlowsky JK, Lederman MM, Feng Z, Weinberg A, Sieg SF, et al. The Toll-like receptor $1 / 2$ agonists Pam(3) CSK(4) and human betadefensin-3 differentially induce interleukin-10 and nuclear factor-kappaB signalling patterns in human monocytes. Immunology. (2011) 134:15160. doi: $10.1111 / \mathrm{j} .1365-2567.2011 .03475 . \mathrm{x}$

63. Lioi AB, Rodriguez AL, Funderburg NT, Feng Z, Weinberg A, Sieg SF. Membrane damage and repair in primary monocytes exposed to human B-defensin-3. J Leukoc Biol. (2012) 92:1083-91. doi: 10.1189/jlb.0112046

64. Lioi AB, Ferrari BM, Dubyak GR, Weinberg A, Sieg SF. Human $\beta$ defensin-3 increases CD86 expression on monocytes by activating the ATP-gated channel P2X7. J Immunol. (2015) 195:4438-45. doi: 10.4049/jimmunol.1401319

65. Biragyn A, Ruffini PA, Leifer CA, Klyushnenkova E, Shakhov A, Chertov $\mathrm{O}$, et al. Toll-like receptor 4-dependent activation of dendritic cells by beta-defensin 2. Science. (2002) 298:1025-9. doi: 10.1126/science.1075565

66. Tewary P, de la Rosa G, Sharma N, Rodriguez LG, Tarasov SG, Howard OZ, et al. $\beta$-Defensin 2 and 3 promote the uptake of self or CpG DNA, enhance IFN- $\alpha$ production by human plasmacytoid dendritic cells, and promote inflammation. J Immunol. (2013) 191:86574. doi: 10.4049/jimmunol.1201648

67. Lande R, Chamilos G, Ganguly D, Demaria O, Frasca L, Durr S, et al. Cationic antimicrobial peptides in psoriatic skin cooperate to break innate tolerance to self-DNA. Eur J Immunol. (2015) 45:20313. doi: 10.1002/eji.201344277

68. McGlasson SL, Semple F, MacPherson H, Gray M, Davidson D, Dorin JR. Human $\beta$-defensin 3 increases the TLR9-dependent response to bacterial DNA. Eur J Immunol. (2017) 47:658-64. doi: 10.1002/eji.201646799

69. Lee JY, Suh JS, Kim JM, Kim JH, Park HJ, Park YJ, et al. Identification of a cell-penetrating peptide domain from human beta-defensin 3 and characterization of its anti-inflammatory activity. Int J Nanomedicine. (2015) 10:5423-34. doi: 10.2147/IJN.S90014

70. Schmidt NW, Jin F, Lande R, Curk T, Xian W, Lee C, et al. Liquid-crystalline ordering of antimicrobial peptide-DNA complexes controls TLR9 activation. Nat Mater. (2015) 14:696-700. doi: 10.1038/nmat4298

71. Lee EY, Lee MW, Wong GC. Modulation of toll-like receptor signaling by antimicrobial peptides. Semin Cell Dev Biol. (2019) 88:173-84. doi: 10.1016/j.semcdb.2018.02.002

72. Barabas N, Röhrl J, Holler E, Hehlgans T. Beta-defensins activate macrophages and synergize in pro-inflammatory cytokine expression induced by TLR ligands. Immunobiology. (2013) 218:1005-11. doi: 10.1016/j.imbio.2012.11.007
73. Semple F, MacPherson H, Webb S, Kilanowski F, Lettice L, McGlasson S, et al. Human b-D-3 exacerbatesMDA5 but suppresses TLR3 responses to the viral molecular pattern mimic polyinosinic:polycytidylic acid. PLoS Genet. (2015) 11:e1005673. doi: 10.1371/journal.pgen.1005673

74. Hancock RE, Haney EF, Gill EE. The immunology of host defence peptides: beyond antimicrobial activity. Nat Rev Immunol. (2016) 16:32134. doi: 10.1038/nri.2016.29

75. Zhang LJ, Sen GL, Ward NL, Johnston A, Chun K, Chen Y, et al. Antimicrobial peptide LL37 and MAVS signaling drive interferon- $\beta$ production by epidermal keratinocytes during skin injury. Immunity. (2016) 45:119-30. doi: 10.1016/j.immuni.2016.06.021

76. Lee EY, Takahashi T, Curk T, Dobnikar J, Gallo R, Wong GC, et al. Crystallinity of double-stranded RNA-antimicrobial peptide complexes modulates toll-like receptor 3-mediated inflammation. ACS Nano. (2017) 11:12145-55. doi: 10.1021/acsnano.7b05234

77. Ahmad S, Mu X, Yang F, Greenwald E, Park J, Hur W, et al. Breaching selftolerance to Alu duplex RNA underlies MDA5-mediated inflammation. Cell. (2018) 172:797-810.e13. doi: 10.1016/j.cell.2017.12.016

78. Subramanian H, Gupta K, Lee D, Bayir AK, Ahn H, Ali H. $\beta$-Defensins activate human mast cells via Mas-related gene X2. J Immunol. (2013) 191:345-52. doi: 10.4049/jimmunol.1300023

79. Judge CJ, Reyes-Aviles E, Conry SJ, Sieg S, Feng Z, Weinberg A, et al. HBD-3 induces NK cell activation, IFN- $\gamma$ secretion and $\mathrm{mDC}$ dependent cytolytic function. Cell Immunol. (2015) 297:61-8. doi: 10.1016/j.cellimm.2015. 06.004

80. Nagaoka I, Niyonsaba F, Tsutsumi-Ishii Y, Tamura H, Hirata M. Evaluation of the effect of human beta-defensins on neutrophil apoptosis. Int Immunol. (2008) 20:543-53. doi: 10.1093/intimm/dxn012

81. Leelakanok N, Fischer CL, Bates AM, Guthmiller J, Johnson GK, Salem AK, et al. Cytotoxicity of HBD3 for dendritic cells, normal human epidermal keratinocytes, hTERT keratinocytes, and primary oral gingival epithelial keratinocytes in cell culture conditions. Toxicol Lett. (2015) 239:906. doi: 10.1016/j.toxlet.2015.09.006

82. Nix MA, Kaelin CB, Palomino R, Miller J, Barsh GS, Millhauser GL. Electrostatic similarity analysis of human $\beta$ defensin binding in the melanocortin system. Biophys J. (2015) 109:1946-58. doi: 10.1016/j.bpj.2015.09.005

83. Candille SI, Kaelin CB, Cattanach BM, Yu B, Thompson DA, Nix MA, et al. A $\beta$-defensin mutation causes black coat color in domestic dogs. Science. (2007) 318:1418-23. doi: 10.1126/science.1147880

84. Feng Z, Dubyak GR, Lederman MM, Weinberg A. Cutting edge: human beta defensin 3-a novel antagonist of the HIV-1 coreceptor CXCR4. J Immunol. (2006) 177:782-6. doi: 10.4049/jimmunol.177.2.782

85. Feng Z, Dubyak GR, Jia X, Lubkowski JT, Weinberg A. Human $\beta$-defensin-3 structure motifs that are important in CXCR4 antagonism. FEBS J. (2013) 280:3365-75. doi: 10.1111/febs.12328

86. Abujaber R, Shea PR, McLaren PJ, Lakhi S, Gilmour J, Allen S, et al. IAVI Africa HIV prevention partnership: no evidence for association of $\beta$ defensin genomic copy number with HIV susceptibility, HIV load during clinical latency, or progression to AIDS. Ann Hum Genet. (2017) 81:2734. doi: 10.1111/ahg.12182

87. Semple F, Webb S, Li HN, Patel HB, Perretti M, Jackson IJ, et al. Human $\beta$-defensin 3 has immunosuppressive activity in vitro and in vivo. Eur J Immunol. (2010) 40:1073-8. doi: 10.1002/eji.2009 40041

88. Lyu J, Bian T, Chen B, Cui D, Li L, Gong L, Yan F. $\beta$-defensin 3 modulates macrophage activation and orientation during acute inflammatory response to Porphyromonas gingivalis lipopolysaccharide. Cytokine. (2017) 92:4854. doi: 10.1016/j.cyto.2016.12.015

89. Semple F, MacPherson H, Webb S, Cox SL, Mallin L, Tyrrell C, et al. Human beta-defensin 3 affects the activity of pro-inflammatory pathways associated with MyD88 and TRIF. Eur J Immunol. (2011) 41:3291300. doi: 10.1002/eji.201141648

90. Koeninger L, Armbruster NS, Brinch KS, Kjaerulf S, Andersen $B$, Langnau $C$, et al. Human $\beta$-Defensin. 2 mediated immune modulation as treatment for experimental colitis. Front Immunol. (2020) 11:93. doi: $10.3389 /$ fimmu. 2020.00093 
91. Wu M, McClellan SA, Barrett RP, Zhang Y, Hazlett LD. Beta-defensins 2 and 3 together promote resistance to Pseudomonas aeruginosa keratitis. $J$ Immunol. (2009) 183:8054-60. doi: 10.4049/jimmunol.0902140

92. Wu Y, Li D, Wang Y, Liu X, Zhang Y, Qu W, et al. Beta-defensin 2 and 3 promote bacterial clearance of Pseudomonas aeruginosa by inhibiting macrophage autophagy through downregulation of early growth response gene-1 and c-FOS. Front Immunol. (2018) 9:211. doi: 10.3389/fimmu.2018.00211

93. Navid F, Boniotto M, Walker C, Ahrens K, Proksch E, Sparwasser T, et al. Induction of regulatory $\mathrm{T}$ cells by a murine $\beta$-defensin. J Immunol. (2012) 188:735-43. doi: 10.4049/jimmunol.1100452

94. Bruhs A, Schwarz T, Schwarz A. Prevention and mitigation of experimental autoimmune encephalomyelitis by murine $\beta$-defensins via induction of regulatory $\mathrm{T}$ cells. J Invest Dermatol. (2016) 136:173-81. doi: 10.1038/JID.2015.405

95. Miani M, Le Naour J, Waeckel-Enée E, chand Verma S, Straube M, Emond P, et al. Gut microbiota-stimulated innate lymphoid cells support $\beta$-defensin 14 expression in pancreatic endocrine cells, preventing autoimmune diabetes. Cell Metab. (2018) 28:557-72. doi: 10.1016/j.cmet.2018.06.012

96. Galkowska H, Olszewski WL, Wojewodzka U. Expression of natural antimicrobial peptide beta-defensin-2 and Langerhans cell accumulation in epidermis from human non-healing leg ulcers. Folia Histochem Cytobiol. (2005) 43:133-6. doi: 10.1097/00024382-200403001-00552

97. Williams H, Campbell L, Crompton RA, Singh G, McHugh B, Davidson DJ, et al. Microbial host interactions and impaired wound healing in mice and humans: defining a role for BD14 and NOD2. J Invest Dermatol. (2018) 138:2264. doi: 10.1016/j.jid.2018.04.014

98. van Kilsdonk JW, Jansen PA, van den Bogaard EH, Bos C, Bergers M, Zeeuwen PL, et al. The effects of human beta-defensins on skin cells in vitro. Dermatology. (2017) 233:155. doi: 10.1159/000477346

99. Otte JM, Werner I, Brand S, Chromik AM, Schmitz F, Kleine M, et al. Human beta defensin 2 promotes intestinal wound healing in vitro. J Cell Biochem. (2008) 104:2286-97. doi: 10.1002/jcb.21787

100. Mi B, Liu J, Liu Y, Hu L, Panayi A, Liu C, et al. The designer antimicrobial peptide A-hBD-2 facilitates skin wound healing by stimulating keratinocyte migration and proliferation. Cell Physiol Biochem. (2018) 51:647-63. doi: 10.1159/000495320

101. Ishida Y, Kuninaka Y, Nosaka M, Furuta M, Kimura A, Taruya A, et al. Kondo: CCL2-mediated reversal of impaired skin wound healing in diabetic mice by normalization of neovascularization and collagen accumulation. J Invest Dermatol. (2019) 139:2517-27.e5. doi: 10.1016/j.jid.2019. 05.022

102. Sato T, Yamamoto M, Shimosato T, Klinman DM. Accelerated wound healing mediated by activation of Toll-like receptor 9. Wound Repair Regen. (2010) 18:586-93. doi: 10.1111/j.1524-475X.2010.00632.x

103. Dasu M, Jialal RI. Amelioration in wound healing in diabetic tolllike receptor-4 knockout mice. J Diabetes Complications. (2013) 27:41721. doi: 10.1016/j.jdiacomp.2013.05.002

104. Ghosh SK, McCormick T, Weinberg SA. Human beta defensins and cancer: contradictions and common ground. Front Oncol. (2019) 9:341. doi: 10.3389/fonc.2019.00341

105. Aldhous MC, Noble CL, Satsangi J. Dysregulation of human betadefensin-2 protein in inflammatory bowel disease. PLoS ONE. (2009) 4:e6285. doi: 10.1371/journal.pone.0006285

106. de Jongh GJ, Zeeuwen PL, Kucharekova M, Pfundt R, van der Valk PG, Blokx W, et al. High expression levels of keratinocyte antimicrobial proteins in psoriasis compared with atopic dermatitis. J Invest Dermatol. (2005) 125:1163-73. doi: 10.1111/j.0022-202X.2005.23935.x

107. Kanda N, Kamata M, Tada Y, Ishikawa T, Sato S, Watanabe S. Human $\beta$-defensin-2 enhances IFN- $\gamma$ and IL-10 production and suppresses IL17 production in T cells. J Leukoc Biol. (2011) 89:935. doi: 10.1189/jlb.01 11004

108. Hollox EJ, Huffmeier U, Zeeuwen PL, Palla R, Lascorz J, Rodijk-Olthuis $\mathrm{D}$, et al. Psoriasis is associated with increased beta-defensin genomic copy number. Nat Genet. (2008) 40:23-5. doi: 10.1038/ng.2007.48

109. Harder J, Bartels J, Christophers E, Schröder JM. A peptide antibiotic from human skin. Nature. (1997) 387:861. doi: 10.1038/43088
110. Jansen PA, Rodijk-Olthuis D, Hollox EJ, Kamsteeg M, Tjabringa GS, de Jongh GJ, et al. Beta-defensin-2 protein is a serum biomarker for disease activity in psoriasis and reaches biologically relevant concentrations in lesional skin. PLoS ONE. (2009) 4:e4725. doi: 10.1371/journal.pone.0004725

111. Wang F, Zhang $\mathrm{X}$, Xia $\mathrm{P}$, Zhang L, Zhang Z. Enhancement of mRNA expression of survivin and human beta-defensin-3 in lesions of psoriasis vulgaris. Eur J Dermatol. (2016) 26:28-33. doi: 10.1684/ejd.201 5.2698

112. Rácz E, Prens EP, Kurek D, Kant M, De Ridder D, Mourits S, et al. Effective treatment of psoriasis with narrow-band UVB phototherapy is linked to suppression of the IFN and Th17 pathways. J Invest Dermatol. (2011) 131:1547-58. doi: 10.1038/jid.2011.53

113. La Mantia L, Capsoni F. Psoriasis during interferon beta treatment for multiple sclerosis. Neurol Sci. (2010) 31:3379. doi: 10.1007/s10072-009-0184-X

114. Li Y, Liao W, Cargill M, Chang M, Matsunami N, Feng B, et al. Carriers of rare missense variants in IFIH1 are protected from psoriasis. J Invest Dermatol. (2010) 130:2768-72. doi: 10.1038/jid.2010.214

115. de Carvalho LM, Ngoumou G, Park JW, Ehmke N, Deigendesch N, Kitabayashi $\mathrm{N}$, et al. Musculoskeletal disease in MDA5-related type i interferonopathy: a mendelian mimic of jaccoud's arthropathy. Arthritis Rheumatol. (2017) 69:2081-91. doi: 10.1002/art.40179

116. Chieosilapatham P, Ogawa H, Niyonsaba F. Current insights into the role of human $\beta$-defensins in atopic dermatitis. Clin Exp Immunol. (2017) 190:15566. doi: 10.1111/cei.13013

117. Wollenberg A, Bieber T. Atopic dermatitis: from the genes to skin lesions. Allergy. (2000) 55:205. doi: 10.1034/j.1398-9995.2000.0 0115.x

118. Ong PY, Ohtake T, Brandt C, Strickland I, Boguniewicz M, Ganz $\mathrm{T}$, et al. Endogenous antimicrobial peptides and skin infections in atopic dermatitis. N Engl J Med. (2002) 347:1151. doi: 10.1056/NEJMoa 021481

119. Howell MD, Boguniewicz M, Pastore S, Novak N, Bieber T, Girolomoni G, et al. Mechanism of HBD-3 deficiency in atopic dermatitis. Clin Immunol. (2006) 121:332. doi: 10.1016/j.clim.2006.08.008

120. Kanda N, Watanabe $S$. Increased serum human $\beta$-defensin- 2 levels in atopic dermatitis: relationship to IL-22 and oncostatin M. Immunobiology. (2012) 217:436-45. doi: 10.1016/j.imbio.2011.10.010

121. Kisich KO, Carspecken CW, Fiéve S, Boguniewicz M, Leung DYM. Defective killing of Staphylococcus aureus in atopic dermatitis is associated with reduced mobilization of human $\beta$-defensin-3. J Allergy Clin Immunol. (2008) 122:62. doi: 10.1016/j.jaci.2008.04.022

122. Kiatsurayanon C, Niyonsaba F, Smithrithee R, Akiyama T, Ushio H, Hara $M$, et al. Host defense (Antimicrobial) peptide, human $\beta$-defensin3 , improves the function of the epithelial tight-junction barrier in human keratinocytes. J Invest Dermatol. (2014) 134:2163-73. doi: 10.1038/jid.20 14.143

123. Wang B, McHugh BJ, Qureshi A, Campopiano DJ, Clarke DJ, Fitzgeral JR, et al. IL-1 $\beta$-Induced Protection of Keratinocytes against Staphylococcus aureus-Secreted Proteases Is Mediated by Human $\beta$ Defensin 2. J Invest Dermatol. (2017) 137:95. doi: 10.1016/j.jid.2016. 08.025

124. Jones DE, Bevins CL. Paneth cells of the human small intestine express an antimicrobial peptide gene. J Biol Chem. (1992) 267:23216.

125. Jones DE, Bevins CL. Defensin-6 mRNA in human Paneth cells: implications for antimicrobia peptides in host defense of the human bowel. FEBS Lett. (1993) 315:187. doi: 10.1016/0014-5793(93)81160-2

126. Ericksen B, Wu Z, Lu W, Lehrer RI. Antibacterial activity and specificity of the six human $\alpha$-defensins. Antimicrob Agents Chemother. (2005) 49:269. doi: 10.1128/AAC.49.1.269-275.2005

127. Grigat J, Soruri A, Forssmann U, Riggert J, Zwirner J. Chemoattraction of macrophages, $\mathrm{T}$ lymphocytes, and mast cells is evolutionarily conserved within the human $\alpha$-defensin family. J Immunol. (2007) 179:3958. doi: 10.4049/jimmunol.179.6.3958

128. Wehkamp J, Salzman NH, Porter E, Nuding S, Weichenthal M, Petras RE, et al. Reduced Paneth cell $\alpha$-defensins in ileal Crohn's disease. Proc Natl Acad Sci. (2005) 102:18129. doi: 10.1073/pnas.0505256102 
129. Coretti L, Natale A, Cuomo M, Florio E, Keller S, Lembo F, et al. The interplay between defensins and microbiota in crohn's disease. Mediat Inflamm. (2017) 1-8. doi: 10.1155/2017/8392523

130. De Santa Barbara P, Van Den Brink GR, Roberts DJ. Development and differentiation of the intestinal epithelium. Cell Mol Life Sci. (2003) 60:1322. doi: 10.1007/s00018-003-2289-3

131. O’Neil DA, Porter EM, Elewaut D, Anderson GM, Eckmann L, Ganz T, et al. Expression and regulation of the human $\beta$-defensins hBD-1 and hBD-2 in Intestinal Epithelium. J Immunol. (1999) 163:6718.

132. O’Neil DA, Cole SP, Martin-Porter E, Housley MP, Liu L, Ganz T, et al. Regulation of human beta-defensins by gastric epithelial cells in response to infection with Helicobacter pylori or stimulation with interleukin-1. Infect Immun. (2000) 68:5412-5. doi: 10.1128/IAI.68.9.5412-5415.2000

133. Wehkamp J, Harder J, Weichenthal M, Mueller O, Herrlinger K, Stange $\mathrm{R}$, et al. Inducible and constitutive $\beta$-defensins are differentially expressed in crohn's disease and ulcerative colitis. Inflamm Bowel Dis. (2003) 9:215. doi: 10.1097/00054725-200307000-00001

134. Fellermann K, Stange DE, Schaeffeler E, Schmalzl H, Wehkamp J, Bevins CL, et al. A chromosome 8 gene-cluster polymorphism with low human beta- defensin 2 gene copy number predisposes to Crohn disease of the colon. Am J Hum Genet. (2006) 79:439-48. doi: 10.1086/505915

135. Wehkamp J, Fellermann K, Herrlinger K, Baxmann S, Schmidt K, Schwind B, et al. Stange: Human $\beta$-defensin 2 but not $\beta$-defensin 1 is expressed preferentially in colonic mucosa of inflammatory bowel disease. Eur J Gastroenterol Hepatol. (2002) 14:745. doi: 10.1097/00042737-20020700000006

Conflict of Interest: The authors declare that the research was conducted in the absence of any commercial or financial relationships that could be construed as a potential conflict of interest.

Copyright (c) 2020 Shelley, Davidson and Dorin. This is an open-access article distributed under the terms of the Creative Commons Attribution License (CC BY). The use, distribution or reproduction in other forums is permitted, provided the original author(s) and the copyright owner(s) are credited and that the original publication in this journal is cited, in accordance with accepted academic practice. No use, distribution or reproduction is permitted which does not comply with these terms. 